
VOLUME 10 NOMOR 4 AGUSTUS 2021

ISSN : 2303-1514 | E-ISSN : 2598-5949

\title{
DEVELOPING BILINGUAL PICTURE BOOKS MEDIA AS A TOOL OF LITERARY APPRECIATION AT GRADE IV OF ELEMENTARY SCHOOL
}

\author{
Khusnul Khotimah ${ }^{1}$, Rina Yuliana ${ }^{2}$, Sundawati Tisnasari ${ }^{3}$ \\ ${ }^{1,2,3}$ Program Studi Pendidikan Guru Sekolah Dasar, FKIP Universitas Sultan Ageng Tirtayasa, Indonesia \\ ${ }^{1}$ khusnulunul123@gmail.com, ${ }^{2}$ rinayuliana@untirta.ac.id, ${ }^{3}$ sundawati_tisnasari@untirta.ac.id
}

\begin{abstract}
PENGEMBANGAN MEDIA BUKU CERITA BERGAMBAR DWIBAHASA SEBAGAI SARANA APRESIASI SASTRA KELAS IV SEKOLAH DASAR
\end{abstract}

\begin{tabular}{|c|c|}
\hline ARTICLE HISTORY & ABSTRACT \\
\hline $\begin{array}{l}\text { Submitted: } \\
07 \text { Agustus } 2020 \\
07^{\text {th }} \text { August } 2020\end{array}$ & $\begin{array}{l}\text { Abstract: This study aimed to find out the development of bilingual picture book media as a } \\
\text { tool of literary appreciation at grade IV of elementary school, to determine the feasibility of the } \\
\text { bilingual picture book, and to find out students' response to the bilingual picture book media. } \\
\text { This research was conducted at SDN Kotasari involving } 22 \text { students in class IV-A. } 10 \text { students } \\
\text { were tested in a limited trial. The type of research referred to the Borg and Gall model } \\
\text { modified by Sugiyono. This model consisted of six stages namely problem analysis, data } \\
\text { collection, product design, design validation, design revision and product trial. The } \\
\text { instruments used were questionnaires for media validation by lecturers and student } \\
\text { questionnaire sheets. Based on the data analysis, several findings were obtained, among } \\
\text { others, the quality of the bilingual picture book was categorized as very feasible with a } \\
\text { percentage of } 86 \% \text { according to two media experts, very feasible with a percentage of } 82.5 \% \\
\text { according to two linguists, and } 91.5 \% \text { according to two material experts. Then, the percentage } \\
\text { from the students' responses was } 89 \% \text { with very good category. Thus, it was concluded that } \\
\text { bilingual picture book media could be used in learning literary appreciation at grade IV of } \\
\text { elementary school. }\end{array}$ \\
\hline
\end{tabular}

Accepted:

14 Juni 2021

$14^{\text {th }}$ June 2021

Published:

25 Agustus 2021

$25^{\text {th }}$ August 2021

Keywords: literary appreciation, bilingual picture story book

\begin{abstract}
Abstrak: Penelitian ini bertujuan untuk mengetahui cara mengembangkan media buku cerita bergambar dwibahasa sebagai sarana apresiasi sastra di kelas IV sekolah dasar, untuk mengetahui kelayakan media buku cerita bergambar dwibahasa yang dikembangkan, dan untuk mengetahui respons peserta didik terhadap media buku cerita bergambar dwibahasa. Penelitian ini dilakukan di SDN Kotasari dengan subjek penelitian peserta didik kelas IV-A sejumlah 22 orang dengan rincian 10 orang pada uji coba terbatas. Jenis penelitian ini mengacu pada model Borg and Gall yang dimodifikasi oleh Sugiyono. Model ini terdiri dari enam tahap yaitu analisis masalah, pengumpulan data, desain produk, validasi desain, revisi desain dan uji coba produk. Instrumen yang digunakan berupa lembar angket untuk validasi media oleh dosen dan lembar angket peserta didik. Berdasarkan analisis data tersebut, terdapat beberapa temuan antara lain, kualitas buku cerita bergambar dwibahasa yang dikembangkan termasuk kategori sangat layak dengan persentase $86 \%$ dari dua ahli media, kategori sangat layak dengan persentase $82.5 \%$ dari dua ahli bahasa, dan $91.5 \%$ dari dua ahli materi. Respons peserta didik terhadap buku cerita bergambar dwibahasa pada uji coba dengan 10 responden sebesar 89\% dengan kategori sangat baik. Dengan demikian, dapat simpulkan bahwa media buku cerita bergambar dwibahasa dapat digunakan dalam pembelajaran apresiasi sastra di kelas IV sekolah dasar.
\end{abstract}

Kata Kunci : apresiasi sastra, buku cerita bergambar dwibahasa

\section{CITATION}

Khotimah, K., Yuliana, R., \& Tisnasari, S. (2021). Developing Bilingual Picture Books Media as A Tool of Leterary Appreciation at Grade IV Elementary School. Primary: Jurnal $\begin{array}{llllll}\text { Pendidikan Guru Sekolah Dasar, } 10 \text { (4), 766-776. DOI: } & \end{array}$ http://dx.doi.org/10.33578/jpfkip.v10i4.8070. 


\section{PENDAHULUAN}

Sastra anak merupakan suatu karya yang berisi cerita untuk dibaca dan dipahami anak-anak. Tarigan (2011: 5) mengartikan sastra anak adalah sastra yang mencerminkan perasaan dan pengalaman anak-anak masa kini, yang dapat dilihat dan dipahami melalui mata anak-anak atau dikenal dengan through the eyes of child. Pembelajaran apresiasi sastra di sekolah dasar disajikan dengan berbagai kegiatan keterampilan berbahasa. Salah satu kegiatan yang dapat dilakukan untuk mengajak peserta didik mengenal dan mengapresiasi sastra adalah membaca buku cerita anak. Cerita fiksi termasuk sastra anak kelas tinggi. Cerita fiksi merupakan cerita yang berisi kehidupan yang dituangkan dalam bentuk khayalan belaka. Suhita dan Rahmah (2018: 37) menyebutkan jenis cerita fiksi anak, yakni cerita bergambar untuk anak, cerpen anak, dan novel untuk anak-anak. Kegiatan mengapresiasi sastra memiliki peranan penting dalam pendidikan di sekolah dasar karena memiliki segudang manfaat bagi siapa saja yang menikmatinya. Aminuddin (2004: 63) menuturkan bahwa manfaat yang diperoleh seseorang setelah membaca karya sastra antara lain, dapat dijadikan pengisi waktu luang, pemerolehan hiburan, mendapatkan informasi, dan tumbuhnya nilai budaya dari waktu karya itu diciptakan.

Senada dengan Suprani (2018: 233) yang memaparkan nilai-nilai sastra bagi pendidikan anak, antara lain membantu menambah kosakata dalam berbahasa, akan menyerap pengetahuan yang lebih sehingga dapat berpikir kritis, pesan yang terkandung dalam suatu karya sastra secara tidak sadar dapat memberikan pengaruh besar terhadap pembentukan sikap, dan membantu perkembangan sosial peserta didik. Pernyataan tersebut memberikan indikasi bahwa kegiatan apresiasi sastra memuat nilai positif bagi peserta didik. Namun, seiring perkembangan zaman peserta didik justru memiliki minat yang rendah terhadap buku-buku sastra. Hal tersebut disebabkan karena beberapa faktor.
Pembelajaran sastra di sekolah dasar dalam lingkup kurikulum 2013 hanya muatan tambahan atau dapat dikatakan sebagai bumbu pembelajaran tematik saja karena tidak begitu terlihat jelas materinya. Djuanda (2014: 191) memaparkan hasil analisisnya bahwa sastra dalam isi Buku Guru dan Buku Siswa Kurikulum 2013 kurang memadai karena Kompetensi Dasar sudah dipetakan secara tematik integratif, berbeda dalam kurikulum 2006 yang mengisyaratkan bahwa setiap peserta didik jenjang sekolah dasar wajib membaca sembilan buku sastra (puisi anak, buku cerita anak, drama anak, dan dongeng atau cerita rakyat). Hal tersebut memberikan kesempatan kepada pendidik untuk mengembangkan kreativitasnya dalam menumbuhkan apresiasi sastra di sekolah.

Berdasarkan hasil wawancara dengan wali kelas IV A yang bernama Bapak Halabi, M.Pd menyatakan bahwa di perpustakaan SD Negeri Kotasari memiliki banyak koleksi buku cerita bergambar dengan dua bahasa, hanya saja menggunakan Bahasa Indonesia dan Bahasa Inggris. Sekolah tersebut belum menyediakan buku cerita bergambar dengan menggunakan bahasa daerah. Selain itu, pendidik merasa kesulitan dalam mempersiapkan sarana pendukung berupa media pembelajaran yang menarik minat peserta didik dalam membaca sastra. Pendidik hanya mengarahkan peserta didik untuk menyimak dan mendengarkan cerita melalui video. Pendidik tidak mengarahkan peserta didik untuk melakukan kegiatan membaca cerita menggunakan buku cerita yang menarik. Minat peserta didik untuk membaca dan mengapresiasi buku sastra anak cenderung berekurang. Oleh sebab itu, dibutuhkan buku cerita bergambar dwibahasa untuk menunjang pembelajaran apresiasi sastra.

Pendidik berperan penting dalam menyediakan media pembelajaran apresiasi sastra. Gagne dalam Jamaludin (2017: 124) mengartikan media sebagai berbagai berbagai unsur yang berkaitan dengan dunia peserta didik yang bisa membangkitkan semangat 
dalam mengikuti pembelajaran. Berdasarkan pernyataan Gagne tersebut, telah jelas bahwa guru sangat berperan penting dalam mengembangkan media agar memberikan motivasi saat peserta didik belajar mengapresiasi sastra.

Salah satu sarana untuk pembelajaran apresiasi sastra di sekolah dasar adalah mengajak peserta didik untuk akrab dengan buku-buku cerita bergambar. Buku cerita bergambar berupa suatu bentuk kartun dan berwarna akan lebih menarik peserta didik untuk membaca dan mengapresiasi buku bacaan tersebut. Sebagaimana Mandarani dan Ernawati (2017: 26) menemukan dalam penelitiannya yang mengkaji minat membaca peserta didik sekolah dasar melalui sastra anak. Hasil dari penelitian tesebut menyatakan bahwa sebagian besar peserta didik lebih menyukai membaca buku bergambar atau komik karena sangat menarik untuk dibaca. Adapun hasil penelitian yang dilakukan oleh Ngura (2018: 6) yang menegaskan bahwa buku cerita bergambar layak dan efektif untuk meningkatkan kemampuan bercerita dan perkembangan sosial anak.

Media buku cerita bergambar yang dikembangkan juga menambah ruang bagi kepada peserta didik untuk mengenal dan mempelajari bahasa daerah disamping bahasa Indonesia. Buku cerita bergambar dikembangkan dengan dwibahasa, yaitu bahasa Indonesia dan bahasa Jawa Banten. Hal ini bertujuan untuk melestarikan salah satu identitas bangsa yang kini mulai luntur keberadaannya. Bahasa Jawa Banten merupakan warisan budaya sejak Kesultanan Banten yang sampai sekarang masih terus dilestarikan oleh sebagian masyarakat Ulumi, dkk (2017: 72). Namun, saat ini bahasa ibu mulai terkikis keberadaannya di kalangan anak-anak. Guru kelas IV SD Negeri Kotasari menuturkan bahwa di sekolah juga tidak ada pembelajaran bahasa daerah Jawa Banten. Padahal, sekolah tersebut merupakan salah satu dari tiga daerah yang sebagian besar masyarakatnya menggunakan bahasa Jawa Banten, yakni Kota Cilegon. Permendikbud No. 67 tahun 2013 menyatakan bahwa peranan bahasa daerah dalam kurikulum tahun 2013 yaitu sebagai muatan lokal dapat diajarkan secara terintegrasi dengan mata pelajaran seni budaya dan prakarya atau diajarkan secara terpisah apabila merasakan perlu untuk memisahkannya.

Berdasarkan uraian yang telah dipaparkan sebelumnya, maka tujuan dari penelitian ini anatara lain, mendeskripsikan langkah pengembangan media buku cerita bergambar dwibahasa, mendeskripsikan kelayakan media buku cerita bergambar dwibahasa, dan mendeskripsikan respons peserta didik terhadap media buku cerita bergambar dwibahasa sebagai sarana apresiasi sastra di kelas IV SD Negeri Kotasari.

\section{METODE PENELITIAN}

Penelitian ini menggunakan metode penelitian dan pengembangan (Reserch And Development dengan tujuan untuk menghasilkan produk media pembelajaran berupa buku cerita bergambar dwibahasa yang akan diterapkan pada peserta didik kelas IV sekolah dasar. Desain penelitian ini dikembangkan oleh Borg \& Gall yang dimodifikasi oleh Sugiyono (2011: 294). 


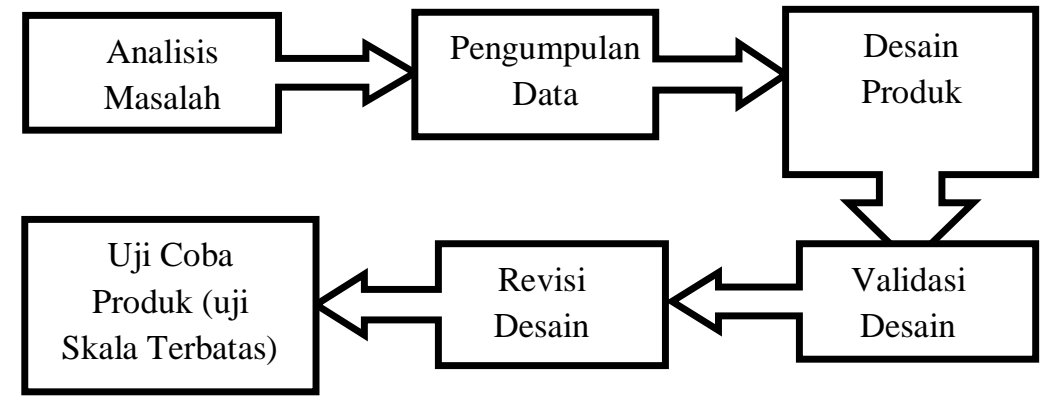

Gambar 1. Alur Modifikasi Metode Research and Development (R\&D) Sugiyono (2011: 408)

Gambar di atas menjelaskan prosedur yang dilaksanakan dalam mengembangkan media cerita bergambar dwibahasa. Berdasarkan gambar tersebut, langkah-langkah penelitian meliputi enam langkah, yaitu analisis masalah, pengumpulan data, desain produk, validasi desain, revisi desain dan uji coba produk. Populasi pada penelitian ini adalah seluruh peserta didik kelas IV A di SD Negeri Kotasari sebanyak 22 orang. Pengambilan sampel dalam penelitian ini dipilih secara teknik Purposive Sampling yakni peserta didik kelas IV A sebanyak 10 orang untuk melakukan uji terbatas. Teknik ini menentukan sampel dengan pertimbangan tertentu sesuai dengan kebutuhan penelitian (Margono, 2007: 128).

Teknik pengumpulan data pada penelitian ini menggunakan wawancara tidak terstruktur, angket (uji ahli dan respons peserta didik), dan dokumentasi. Wawancara tidak terstruktur yaitu jenis wawancara yang hanya memuat garis besar yang akan ditanyakan (Arikunto, 2006: 227). Peneliti melakukan wawancara kepada pihak sekolah yaitu Guru Kelas IV SD Negeri Kotasari untuk mendapatkan data tertentu, berupa bahan ajar, media dan potensi masalah yang ada di sekolah tersebut. Kuesioner (angket) merupakan teknik pengumpulan data yang dilakukan dengan cara memberikan seperangkat pernyataan tertulis kepada responsden untuk dijawabnya (Sugiyono, 2013: 199). Angket dalam penelitian ini digunakan untuk penilaian pengembangan dan kelayakan media pembelajaran, diantaranya angket uji ahli media, uji ahli materi, uji ahli bahasa, dan angket respons peserta didik. Dokumentasi digunakan untuk memperkuat data yang diperoleh dari hasil angket atau kuisioner dan wawancara.

Instrumen yang digunakan untuk mengumpulkan data pada penilitian ini, yaitu a) wawancara guru kelas IV SD Negeri Kotasari terkait analisis kebutuhan buku cerita bergambar dwibahasa, b) angket validasi ahli untuk mengukur kelayakan pada media pembelajaran cerita bergambar dwibahasa, c) Angket respons peserta didik digunakan untuk mengetahui tanggapan peserta didik terhadap buku cerita bergambar dwibahasa.

Analisis data angket uji ahli dilakukan berdasarkan kriteria indikator keberhasilan yaitu memperoleh kriteria minimal $61-80 \%$. Skor yang diperoleh dari penilaian kelayakan oleh uji ahli akan dihitung dengan menggunakan rumus sebagai berikut:

$\mathbf{N P}=\frac{R}{S M} \times 100 \%$

(Purwanto , 2013:102)

NP adalah nilai rata-rata dalam persen (\%) yang diberi, $\mathrm{R}$ adalah skor yang diperoleh dari setiap aspek, dan SM adalah skor maksimum dari seluruh aspek. Nilai yang diperoleh kemudian di interpretasikan sesuai dengan kriteria yang telah ditentukan sebagai berikut: 


\begin{tabular}{ll}
\multicolumn{2}{c}{ Tabel 1. Kriteria Kelayakan Media } \\
\hline \multicolumn{1}{c}{ Presentasi Pencapaian } & \multicolumn{1}{c}{ Kategori Kelayakan } \\
\hline $81 \%-100 \%$ & Sangat layak \\
$61 \%-80 \%$ & Layak \\
$41 \%-60 \%$ & Cukup layak \\
$21 \%-40 \%$ & Kurang Layak \\
$0 \%-20 \%$ & Tidak layak \\
\hline
\end{tabular}

(Sumber: modifikasi Purwanto, 2013: 103

\section{HASIL DAN PEMBAHASAN}

Hasil penelitian dan pengembangan ini buku cerita bergambar dwibahasa ini dilakukan berdasarkan prosedur pengembangan menurut Borg dan Gall yang telah dimodifikasi oleh Sugiyono. Pemilihan prosedur pengembangan ini telah ditetapkan, yaitu melakukan analisis masalah, pengumpulan data, desain produk, validasi desain produk, revisi desain, dan uji coba produk. Pada tahap analisis masalah peneliti melakukan analisis kurikulum, analisis materi dan analisis kebutuhan media buku cerita bergambar dwibahasa.

Analisis kebutuhan dilakukan dengan melakukan wawancara kepada guru. Berdasarkan hasil wawancara dengan wali kelas IV A yang bernama Bapak Halabi, M.Pd menyatakan bahwa di perpustakaan SD Negeri Kotasari memiliki banyak koleksi buku cerita bergambar dengan dua bahasa, hanya saja menggunakan Bahasa Indonesia dan Bahasa Inggris. Sekolah tersebut belum menyediakan buku cerita bergambar dengan menggunakan bahasa daerah. Selain itu, pendidik merasa kesulitan dalam mempersiapkan sarana pendukung berupa media pembelajaran yang menarik minat peserta didik dalam membaca sastra. Pembelajaran sastra terlihat masih monoton karena pendidik hanya mengarahkan peserta didik untuk menyimak dan mendengarkan cerita melalui video. Pendidik tidak mengarahkan peserta didik untuk melakukan kegiatan membaca cerita menggunakan buku cerita yang menarik. Oleh karena itu, sangat dibutuhkan media pembelajaran berupa buku cerita bergambar dwibahasa dengan tampilan menarik dan berwarna.
Tahap selanjutnya, yaitu analisis kurikulum dan materi. Kurikulum yang digunakan di SD Negeri Kotasari adalah Kurikulum 2013. Selanjutnya data yang dikumpulkan berupa studi literature dari data analisis kurikulum, analisis materi, serta analisis kegiatan belajar mengajar Tema $8 \mathrm{Sub}$ Tema 1 Pembelajaran ke 1 dengan menggunakan wawancara tidak terstruktur sehingga dapat dijadikan bahan untuk mengembangkan produk. Adapun judul cerita yang terpilih yaitu "Asal Mula Telaga Warna".

Produk yang dikembangkan berupa buku cerita bergambar diwbahasa. Ukuran buku ini adalah custom size $(20 \mathrm{~cm} \times 15 \mathrm{~cm})$. Font atau jenis huruf yang digunakan pada buku cerita bergambar dwibahasa ini, yakni Comic Sans MS, Segoe Print, dan Segoe Script. Adapun untuk dwibahasa menggunakan warna yang berbeda hal ini agar huruf dapat terlihat dengan jelas sehingga mudah untuk dibaca. Gambar ini dirancang menggunakan teknik gambar manual menggunakan bahan berupa pensil, penghapus, dan spidol.

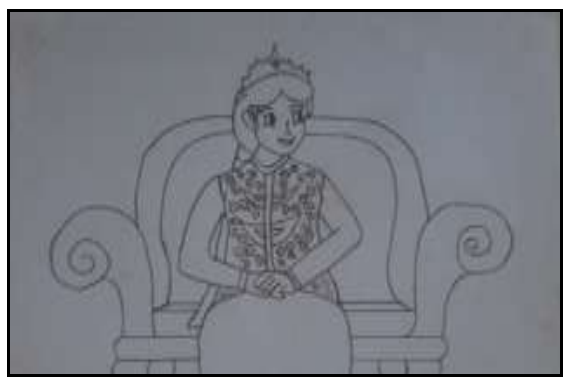

\section{Gambar 2. Gambar Manual Tokoh Utama Cerita}

Tahap selanjutnya adalah scan gambar dan pemberian warna melalui software adobe 
photoshop. Gambar-gambar yang didapat lalu dilakukan proses editing dengan menggunakan aplikasi microsoft power point untuk menambahkan isi cerita, efek, dan background yang akan disesuaikan dengan buku cerita bergambar dwibahasa.



Gambar 3. Gambar Tokoh Utama Cerita Setelah Proses Editing
Produk yang telah dikembangkan harus melewati tahapan validasi (uji ahli) terlebih dahulu sebelum diuji coba ke lapangan. Validasi dilakukan oleh dua ahli media, dua bahasa, dan dua ahli materi yang berkompeten. Tabel di bawah ini merupakan hasil dari angket uji ahli dalam penelitian.

Tabel 2. Hasil Uji Ahli Media

\begin{tabular}{lccc}
\hline \multicolumn{1}{c}{ Aspek Penilaian } & Ahli Media I & Ahli Media II & Total \\
\hline Komponen Buku & & & \\
Verbal & & & \\
Desain Sampul & 97 & 92 & \\
$\begin{array}{l}\text { Desain Isi } \\
\text { Tipografi }\end{array}$ & & & \\
Percetakan & & & \\
\hline Presentase Nilai (\%) & $\mathbf{8 8 \%}$ & $\mathbf{8 4 \%}$ & \\
\hline Rata-Rata & & $\mathbf{8 6 \%}$ & \\
\hline Kriteria & & Sangat Layak \\
\hline
\end{tabular}

Tabel 3. Hasil Uji Ahli Bahasa

\begin{tabular}{|c|c|c|c|}
\hline Aspek Penilaian & $\begin{array}{c}\text { Ahli Bahasa } \\
\text { I }\end{array}$ & $\begin{array}{c}\text { Ahli } \\
\text { Bahasa II }\end{array}$ & Total \\
\hline $\begin{array}{l}\text { Keterbacaan } \\
\text { Kejelasan Informasi }\end{array}$ & & & \\
\hline $\begin{array}{l}\text { Kesesuaian dengan Kaidah Bahasa } \\
\text { Pemanfaatan bahasa secara efektif dan } \\
\text { efisien }\end{array}$ & 97 & 92 & 189 \\
\hline Presentase Nilai (\%) & $88 \%$ & $84 \%$ & \\
\hline Rata-Rata & \multicolumn{2}{|c|}{$86 \%$} & \\
\hline Kriteria & Sangat L & yak & \\
\hline
\end{tabular}


Tabel 4. Hasil Uji Ahli Materi

\begin{tabular}{lccc}
\hline \multicolumn{1}{c}{ Aspek Penilaian } & $\begin{array}{c}\text { Ahli } \\
\text { Materi I }\end{array}$ & $\begin{array}{c}\text { Ahli } \\
\text { Materi II }\end{array}$ & Total \\
\hline $\begin{array}{l}\text { Relevansi Materi } \\
\text { Keakuratan Materi }\end{array}$ & 85 & 89 & 174 \\
$\begin{array}{l}\text { Kemutakhiran Materi } \\
\text { Mendorong Keingintahuan }\end{array}$ & & & \\
\hline Presentase Nilai (\%) & $\mathbf{8 9 \%}$ & $\mathbf{9 4 \%}$ & \\
\hline Rata-Rata & \multicolumn{2}{c}{$\mathbf{9 1 , 5 \%}$} & \\
\hline Kriteria & \multicolumn{2}{c}{ Sangat Layak } \\
\hline
\end{tabular}

Tabel 5. Hasil Respons Peserta Didik

\begin{tabular}{lcccc}
\hline Aspek Penilaian & $\begin{array}{c}\text { Jumlah } \\
\text { Butir }\end{array}$ & $\begin{array}{c}\text { Jumlah } \\
\text { Skor }\end{array}$ & $\begin{array}{c}\text { Jumlah skor } \\
\text { ideal }\end{array}$ & Persentase \\
\hline Tampilan & 7 & 316 & 350 & $90 \%$ \\
Ketertarikan & 4 & 169 & 200 & $85 \%$ \\
Kemanfaatan & 1 & 46 & 50 & $92 \%$ \\
Jumlah & $\mathbf{1 2}$ & $\mathbf{5 3 1}$ & $\mathbf{6 0 0}$ & $\mathbf{2 6 7 \%}$ \\
\hline Rata-rata & & & & $\mathbf{8 8 \%}$ \\
\hline Kategori & & & & Sangat Baik \\
\hline
\end{tabular}

\section{Pembahasan}

Penelitian dilakukan selama 5 bulan, kegiatan penelitian dilaksanakan sejak Maret 2020 sampai dengan Juli 2020. Pengembangan media dilakukan dalam beberapa tahap yakni analisis masalah, pengumpulan data, desain produk, validasi desain produk, perbaikan produk dan uji coba produk. Pada langkah awal, peneliti menentukan analisis masalah (potensi dan masalah). Pada tahap analisis masalah peneliti melakukan analisis kurikulum, materi, dan kebutuhan media buku cerita bergambar dwibahasa. Analisis kebutuhan dilakukan dengan melakukan wawancara kepada guru. Berdasarkan hasil wawancara dengan wali kelas IV A yang bernama Bapak Halabi, M.Pd menyatakan bahwa di perpustakaan SD Negeri Kotasari memiliki banyak koleksi buku cerita bergambar dengan dua bahasa, hanya saja menggunakan Bahasa Indonesia dan Bahasa Inggris.

Kurikulum yang digunakan di SD Negeri Kotasari adalah Kurikulum 2013. Pada analisis kurikulum ini, peneliti mengidentifikasi dan memahami Kompetensi Inti (KI) dan Kompetensi Dasar (KD) pada mata pelajaran Bahasa Indonesia melalui buku guru yang sesuai dengan permasalahan yang peneliti dapat. Setelah peneliti mengidentifikasi KI dan KD pada mata pelajaran Bahasa Indonesia, peneliti menentukan media pembelajaran yang tepat untuk mengatasi permasalahan apresiasi sastra di kelas IV sekolah dasar. Selanjutnya untuk analisis materi, peneliti melakukan analisis KI dan KD pada buku Tema 8 Sub Tema 1 Pembelajaran ke 1.

Setelah dilakukan analisis terhadap tiga aspek tersebut, lalu dilakukan tahapan desain produk, pada tahapan desain produk yakni, pembuatan storyboard yang berguna sebagai rancangan awal. Langkah pertama, yaitu menggambar manual dengan berbagai ilustrasi yang berkaitan dengan isi cerita. Hal tersebut sesuai dengan pendapat Sadiman (2012: 31) yang mengemukakan bahwa gambar yang baik dapat menampakkan kegiatan tertentu yang sedang terjadi dalam suatu cerita. Ilustrasi dalam buku cerita bergambar dwibahasa digambar secara manual menggunakan bahan berupa pensil, penghapus, dan spidol. Langkah kedua, yaitu scan gambar yang telah dibuat dan dan memberikan warna 
dengan software adobe photoshop. Gambargambar yang didapat lalu dilakukan proses editing dengan menggunakan aplikasi microsoft power point untuk menambahkan isi cerita, efek, dan background yang akan disesuaikan dengan buku cerita bergambar dwibahasa.

Adapun ukuran buku setelah dicetak adalah custom size $(20 \mathrm{~cm} \times 15 \mathrm{~cm})$ dengan kertas art paper dan terdiri dari delapan halaman. Nurgiyantoro (2005: 152) menyatakan bahwa jumlah halaman dalam buku cerita bergambar tidak ditentukan. Namun, terkadang buku dengan ketebalan yang lebih membuat anak merasa bosan untuk membacanya. Font atau jenis huruf yang digunakan pada buku cerita bergambar dwibahasa ini yakni Comic Sans MS, Segoe Print, dan Segoe Script. Huruf yang digunakan sesuai dengan ejaan yang disempurnakan. Judul cerita menggunakan jenis huruf berupa Segoe Script. Jenis huruf Comic Sans MS dan Segoe Print digunakan untuk pengantar cerita yang terdapat di dalam buku cerita bergambar dwibahasa. Comic Sans MS digunakan untuk pengantar cerita bahasa Indonesia. Sedangkan Segoe Print sebagai pengantar cerita dengan bahasa Jawa Banten.



Gambar 4. Hasil Akhir Kualitas Produk

Diagram di atas menunjukkan hasil penggabungan penilaian kedua ahli media yakni mencapai persentase $86 \%$ dengan kategori "Sangat Layak". Tim ahli media menyatakan bahwa buku cerita bergambar sesuai untuk peserta didik dan teks yang disajikan sangat jelas. Selain itu, keharmonisan gambar dengan teks yang disajikan sudah terlihat sehingga peserta didik lebih tertarik untuk membaca secara bergantian. Hal tersebut sesuai dengan penelitian yang telah dilakukan oleh Adipta Hendra, dkk (1 (2): 989-992) pada tahun 2016 yang berjudul "Pemanfaatan Buku Cerita Bergambar sebagai Sumber Bacaan Peserta didik SD”. Penelitian tersebut juga diterapkan untuk peserta didik kelas tinggi dan menyatakan bahwa buku cerita bergambar sudah cukup efektif untuk menarik minat peserta didik dalam pembelajaran. Sepadan dengan yang dikemukakan oleh Sukma dan Johari (2015: 8) bahwa salah satu kegiatan apresiasi prosa fiksi, yaitu dengan mengajak peserta didik untuk secara langsung membaca atau mendengarkan bermacam sajak, cerita, maupun drama dari berbagai sastrawan agar memperoleh pemahaman serta menghargai karya sastra secara wajar.

Ahli media menyatakan bahwa buku cerita bergambar dwibahasa yang disajikan sudah dianggap baik untuk peserta didik 
sekolah dasar, akan tetapi masih terdapat beberapa kesalahan dalam penulisan. Buku cerita bergambar dwibahasa akan digunakan oleh peserta didik sekolah dasar kelas tinggi sehingga diperlukan perbaikan agar peserta didik dapat memahami materi yang akan disampaikan oleh penulis sehingga memerlukan perencanaan yang baik dalam penyusunannya. Hal ini senada dengan yang diungkapkan oleh Arsyad (2011:67) bahwa pembelajaran yang efektif memerlukan perencanaan yang baik.

Penilaian dari ahli bahasa mencapai persentase $82,50 \%$ dengan kategori "Sangat Layak". Kedua tim ahli menyatakan bahwa buku cerita bergambar dwibahasa telah memiliki kalimat yang sederhana dan jelas, serta membangkitkan rasa ketertarikan peserta didik untuk bercerita dengan bahasa sendiri. peserta didik. Hasil tersebut diperkuat oleh penelitian-penelitian sebelumnya, seperti yang dilakukan oleh Ngura Elisabeth Tantiana (5 (1): 6-14). Penelitian ini dilakukan pada tahun 2018 dengan judul "Pengembangan Buku Cerita Bergambar untuk Meningkatkan Kemampuan Bercerita dan Perkembangan Sosial Anak". Adapun hasil penelitian tersebut menunjukkan bahwa efektivitas media buku cerita bergambar dapat meningkatkan kemampuan bercerita dan sosial anak. Selaras dengan pendapat yang disampaikan oleh Suprani (2018: 233) bahwa buku cerita merupakan salah satu sastra anak yang secara sadar atau tidak sadar akan meningkatkan pemerolehan bahasa melalui menyimak atau membaca.

Adapun kekurangan yang harus diperbaiki dalam buku cerita bergambar dwibahasa, yaitu masih terdapat kosakata yang kurang sesuai dengan Ejaan Bahasa Indonesia dan Bahasa Jawa Banten. Buku cerita bergambar dwibahasa yang baik harus menyesuaikan dengan kaidah bahasa. Sebagaimana yang dikemukakan oleh Badan Standar Nasional Pendidikan dalam Gustanti (2018: 23) bahwa salah satu unsur kelayakan media teks yaitu kesesuaian pemakaian bahasa dengan tingkat perkembangan anak, pemakaian bahasa yang komunikatif, pemakaian bahasa memenuhi syarat, keruntutan, dan keterpaduan.

Grafik tersebut menunjukkan penilaian kedua ahli materi mencapai nilai rata-rata $91,50 \%$. Berdasarkan grafik di atas, penilaian kedua ahli menunjukkan bahwa buku cerita bergambar dwibahasa mampu mengemas isi cerita sesuai dengan indikator sehingga peserta didik dapat memahami materi. Kegiatan memahami materi tersebut merupakan salah satu langkah dalam mengapresiasi sastra. Pernyataan tersebut selaras dengan pendapat yang dikemukakan oleh Waluyo (2011: 29) bahwa penting menemukan isi dan makna dalam sebuah karya sastra karena keduanya merupakan modal dalam mengapresiasi sebuah karya sastra.

Media cerita bergambar dwibahasa mendapatkan respons dari 10 peserta didik dengan persentase mencapai $88 \%$. Angka tersebut termasuk ke dalam krtiteria "Sangat Baik". Peneliti melakukan tahap uji coba terhadap 10 peserta didik dan memberikan angket respons peserta didik terhadap media buku cerita bergambar dwibahasa yang meliputi tiga aspek, yaitu tampilan, ketertarikan, dan kemanfaatan.

Indikator dalam aspek tampilan, yaitu daya tarik media, kemenarikan gambar dan kemenarikan isi cerita. Daya tarik media sangat erat dengan komponen buku cerita bergambar dwibahasa yaitu gambar dan isi. Gambar yang disajikan dalam buku cerita bergambar dwibahasa merupakan gambar sehari-hari, meliputi segala jenis bentuk karakter tokoh dan ilustrasi yang terjadi dalam sebuah kerajaan. Hal ini sesuai dengan pendapat yang dikemukakan oleh Arsyad dalam Suryani (2018: 48) bahwa media berbasis cetak akan lebih menarik apabila dilengkapi dengan gambar dan warna.

Aspek ketertarikan menunjukkan bahwa peserta didik antusias terhadap kegiatan mengapresiasi sastra menggunakan buku cerita bergambar dwibahasa. Pernyataan tersebut 
diperkuat oleh pendapat Suprani (2018: 239) bahwa salah satu sastra anak sekolah dasar kelas tinggi adalah cerita anak, seperti cerita bergambar untuk anak, serial anak, cerpen anak, dan novel anak. Indikator pada aspek kemanfaatan menunjukkan bahwa media buku cerita bergambar dwibahasa mempermudah pemahaman peserta didik secara mandiri. Artinya, peserta didik dapat melakukan kegiatan apresiasi sastra dengan menggunakan buku cerita bergambar dwibahasa. Selain itu, peserta didik juga dapat mengenal bahasa Jawa Banten dengan buku cerita bergambar dwibahasa. Hal ini sesuai dengan pendapat yang dikemukakan oleh Mitchell dalam Nurgiyantoro (2005: 154) bahwa salah satu manfaat buku cerita bergambar adalah dapat membantu mengapresiasi keindahan.

\section{SIMPULAN DAN REKOMENDASI}

Penelitian ini telah menghasilkan produk berupa buku cerita bergambar dwibahasa sebagai media pembelajaran apresiasi sastra materi cerita fiksi kelas IV SD. Buku cerita bergambar dwibahasa ini memiliki 2 komponen, yaitu gambar dan teks. Gambar disesuaikan dengan teks cerita dan terletak pada sisi kanan buku, sedangkan teks berada di sebelah kiri buku. Bahasa yang digunakan dalam teks adalah bahasa Indonesia dan bahasa Jawa Banten. Media buku cerita bergambar dwibahasa layak digunakan sebagai sarana apresiasi sastra di kelas IV sekolah dasar dengan memperoleh hasil penilaian mencapai persentase $86 \%$ dari dua ahli media, $82,5 \%$ dari dua ahli bahasa, dan $91,5 \%$ dari dua ahli materi. Tingkat kelayakan buku cerita bergambar dwibahasa memperoleh nilai ratarata keseluruhan validasi ahli sebesar $86 \%$ yang masuk dalam kategori "Sangat Layak". Respons peserta didik terhadap buku cerita bergambar dwibahasa sebagai sarana apresiasi sastra di kelas IV sekolah dasar pada uji coba lapangan yang melibatkan 10 peserta didik memperoleh persentase $88 \%$ yang termasuk dalam kategori "Sangat Baik".
Berdasarkan hasil penelitian dan kesimpulan di atas, maka peneliti mengajukan saran untuk meningkatkan kualitas media pembelajaran cerita bergambar dwibahasa, diantaranya: (1) buku cerita bergambar dwibahasa dapat menjadi alat bantu dalam pembelajaran sastra, (2) buku cerita bergambar dwibahasa dapat menjadi alternatif bagi guru agar menjadi sarana apresiasi sastra di sekolah dasar sehingga pembelajaran lebih efektif dan efisien, (3) Sebaiknya mempertimbangkan biaya cetak dengan mencetak buku cerita bergambar dwibahasa dengan jumlah yang sedikit terlebih dahulu sebelum buku lulus uji ahli materi, bahasa, dan media untuk menghindari pemborosan biaya, tenaga, dan waktu penelitian.

\section{DAFTAR PUSTAKA}

Adipta, H. (2016). Pemanfaatan Buku Cerita Bergambar sebagai Sumber Bacaan Siswa SD. Jurnal Pendidikan: Teori, Penelitian, dan Pengembangan, 1(5), 989-992.

Aminuddin. (2004). Pengantar Apresiasi Karya Sastra. Bandung: Sinar Baru Aglesindo.

Arikunto, S. (2006). Penelitian Suatu Pendekatan Praktik. Jakarta: Rineke Cipta.

Arsyad, A. (2011). Media Pembelajaran. Jakarta: PT Raja Grafindo Persada.

Djuanda, D. (2014). Pembelajaran Sastra dalam Gamitan Kurikulum 2013. Jurnal Mimbar Sekolah Dasar Universitas Pendidikan Indonesia Kampus Sumedang, 1(2):192-200.

Gustanti, R. R. (2018). Pengembangan Buku Cerita Bergambar Tema 1 Subtema 1: Aku dan Diriku untuk Siswa Kelas 1 Sekolah Dasar. Skripsi Universitas Sanata Dharma Yogyakarta.

Jamaludin, U., \& Reza, R. (2017). Pembelajaran Pendidikan IPS Teori, Konsep,dan Aplikasi bagi Guru dan Mahasiswa. Bekasi: CV Nurani. 
Mandarani, V., \& Ermawati, Z. N. (2017). Kajian Minat Membaca Siswa terhadap Karya Sastra. Pedagogia: Jurnal Pendidikan, 6(1):26-31.

Margono. (2007). Metodologi Penelitian Pendidikan. Jakarta: Rineka Cipta.

Ngura, E. T. (2018). Pengembangan Media Buku Cerita Bergambar untuk Meningkatkan Kemampuan Bercerita dan Perkembangan Sosial Anak Usia Dini. Jurnal Pendidikan Guru Pendidikan Anak Usia Dini STKIP Citra Bakti, 5(1):6-14.

Nurgiyantoro, B. (2005). Sastra Anak Pengantar Pemahaman Dunia Anak. Yogyakarta: Gadjah Mada University Press.

Purwanto, N. (2013). Prinsip-Prinsip dan Teknik Evaluasi Pengajaran. Bandung: PT Remaja Rosdakarya.

Sadiman, A, S., dkk. (2012). Media Pendidikan Pengertian, Pengembangan, dan Pemanfaatannya. Jakarta: PT Raja Grafindo Persada.

Sugiyono. (2011). Metode Penelitian Kuantitatif, Kualitatif dan $R \& D$. Bandung: Alfabeta.
Sugiyono. (2013). Metode Penelitian Kuantitatif, Kualitatif dan $R \& D$. Bandung: Alfabeta.

Suhita, S., \& Rahmah, P. (2018). Apresiasi Sastra Indonesia dan Pembelajarannya. Bandung: PT Remaja Rosdakarya.

Sukma, E., dan Johari, A. (2016). Kompetensi Kognitif Pembelajaran Apresiasi Sastra di Sekolah Dasar. Jurnal Penelitian Bahasa dan Sastra Indonesia, 2 (1):1-11.

Suprani. (2018). Pembelajaran Bahasa Indonesia di Kelas Rendah Sekolah Dasar. Medan: Harapan Cerdas.

Suryani, N., dkk. (2018). Media Pembelajaran Inovatif dan Pengembangannya. Bandung: PT Remaja Rosdakarya.

Tarigan, H. G. (2011). Dasar-Dasar Psikosastra. Bandung: Angkasa.

Ulumi, H., dkk. (2017). Peta Bahasa Masyarakat Banten. Serang: Laboratorium Bantenologi.

Waluyo, H. J. (2011). Pengkajian Prosa Fiksi. Surakarta: UNS Press. 